JURNAL SENI MUSWK

\title{
The Design Of Mutranesia Applicaton As A Support For Cultural Arts Learning In Indonesian Traditional Music Materials
}

\author{
Asani Gian Haviana ${ }^{\bowtie 1}$ \\ Universitas Pendidikan Indonesia \\ Yudi Sukmayadi \\ Universitas Pendidikan Indonesia \\ Aulia Rahman \\ Universitas Pendidikan Indonesia \\ M. Zakki Mudhofar \\ Universitas Pendidikan Indonesia
}

Article Info

Submitted: June, 2021

Revised : November,2021

Accepted:December,2021

Keywords:

Application, Traditional

Music, Mutranesia
Abstract

The development of science and technology is currently marked by the increasingly advanced field of Technology and Communication (ICT) in various sectors of life, including education. The use of application-based media is widely used during a pandemic. The world of education does not escape the role of digital-based media, such as learning in schools. There are times when students feel bored. Seeing the boredom of students when studying, it is necessary to make an innovation to motivate students to increase their enthusiasm. The author has an idea to create a music application. The purpose of this research is to make it easy for users or teachers and students to understand the material, especially Indonesian traditional music. The method used is Research and Development method and use the waterfall model, which is a systematic and sequential information system development model. Waterfall has the following stages: a. Requirements analysis and definition, b. System and software design, c. Implementation and unit testing, d. Integration and system testing, e. Operations and maintenance. The Mutranesia application is designed to support cultural arts learning in Indonesian traditional music materials. This app has six page views. First, the splash screen display. Second, display the Welcome page. Third, display the about page. Fourth, display the credits page. Fifth, map pages, and sixth, content display. The Mutranesia application is an android-based music application which has the concept of maps. The Mutranesia application is designed to support cultural arts learning in Indonesian traditional music materials. This app has six page views. First, the splash screen display. Second, display the Welcome page. Third, display the about page. Fourth, display the credits page. Fifth, map pages, and sixth, content display. The Mutranesia application is an android-based music application which has the concept of maps. The Mutranesia application is designed to support cultural arts learning in Indonesian traditional music materials. This app has six page views. First, the splash screen display. Second, display the Welcome page. Third, display the about page. Fourth, display the credits page. Fifth, map pages, and sixth, content display. The Mutranesia application is an android-based music application which has the concept of maps 


\section{INTRODUCTION}

The development of science and technology is currently marked by the increasingly advanced field of Information and Communication Technology (ICT) in various sectors of life, including education (Mustika et al., 2020). For the world of education, the rapid flow of information and communication that continues to develop, provides choices in various styles and forms of media, both print, electronic and digital media, resulting in more and more learning resources available that can be utilized.

The use of application-based media is widely used today. Especially in a pandemic, technology media is very dominantly used in the learning process. Likewise in learning music at school. .Various materials are sought by educators to be packaged in such a way as to make it easy for students to understand.

Like learning at school. Cultural arts subjects. In class $\mathrm{x}$ material about Indonesian traditional music. Usually students can directly practice their musical instruments. Due to the pandemic, students can only see and listen and imagine how to play it. .there are also some students who feel bored.

Seeing the boredom of students when studying, it is necessary to make an innovation to motivate students to increase their enthusiasm for learning. The author observes the need for media that facilitates the delivery of the material. .One of the ideas or plans that were launched was to design an Android-based music application that supports learning.

It contains maps and knowledge of traditional Indonesian music. This application plan is called Mutranesia. The purpose of this application is to make it easier and more interesting in learning arts and culture subjects in Indonesian traditional music material.

\section{METHOD}

The method used is Research and Development. According to Sugiyono
(Setiadi et al., 2018), Research and Development method or research development is a research method used to produce certain products and test the effectiveness of these products. This research uses the waterfall development model, which is a systematic and sequential information system development model. Waterfall model (Sasmito et al., 2017) has the following stages:

\section{Requirements analysis and definition}

System services, constraints, and objectives are defined by the results of consultation with users which are then defined in detail and serve as system specifications.

\section{System and software design}

The system design stage allocates system requirements both software by forming the overall system architecture. Software design involves identifying and delineating the basic system abstractions of software and their relationships..

\section{Implementation and unit testing}

At this stage, the software design is realized as a series of programs or program units. Testing involves verifying that each unit meets its specifications..

\section{Integration and system testing}

Individual units of the program or programs are combined and tested as a complete system to ensure whether it meets the requirements of the software or not. After testing, the software can be sent to the customer.

\section{Operation and maintenance}

Usually (though not always), this stage is the longest stage. The system is installed and used for real. Maintenance involves correcting errors that were not found in the previous stages, improving the implementation of the system units and improving system services as new requirements. 


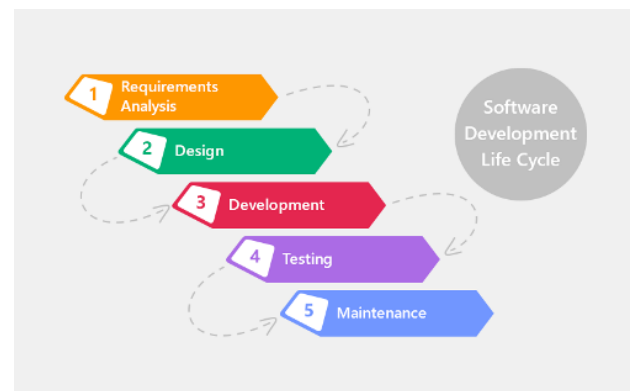

Figure 1. Waterfall metod display (Source: Hestanto)

\section{RESULT AND DISCUSSION}

Learning

Learning is a process of interaction between students and the environment so that changes in behavior occur for the better. In the learning process, the main principle is the involvement of all potential students. This process demands a critical attitude from both the teacher and the learner. .Motivating and engaging students in an active learning process is a challenge even for experienced teachers (Saputra et al., 2013).

Currently, learning requires an innovation such as digital-based learning media, especially Android. The majority of today's students already have a smartphone and can use it. Not only for playing games but used for learning..

Learning arts and culture in schools aims to grow and develop the personality of students, nurture students' aesthetic sense, and enrich students' lives creatively. For learning arts and culture, media is also needed that makes students interested. One of the materials is Indonesian traditional music.

Traditional musical instruments are musical instruments of the local community that are made and passed down from generation to generation, and are sustainable in the community of an area, are culture as a result of human civilization (Hidayati \& Nafiiyah, 2017). In today's era there are still many young people who do not know the roots of culture and traditional musical instrument (Asmara, 2020).

Getting to know musical instruments and traditional Indonesian arts is one of the goals of learning cultural arts at the $\mathrm{X}$ grade high school level. There are many kinds of traditional arts in Indonesia. .The author seeks to pour all data on traditional Indonesian arts into one application to facilitate learning..

\section{Planning}

Design is a process to get the right results by using certain methods, (Fathan et al., n.d.). Design is a process of selecting and thinking that relates facts based on assumptions related to the future by describing and formulating certain activities that are believed to be needed to achieve certain goals.

\section{Application}

The application comes from the English language, namely To Apply which means to apply or apply. It can also be said that the application is a program or software created to solve a problem and facilitate a particular job or purpose (Oktarian, 2020).

Mutranesia application is an android-based music application. It has the concept of maps. Users can use this application by searching for an instrument whose image appears on the map listed. Later information regarding the instrument will appear. .such as history, how to play until the sound of the instrument can be heard.

The following is the design of the Mutranesia application:

1. Splash screen display

The following is the splash screen of the Mutranesia application. 


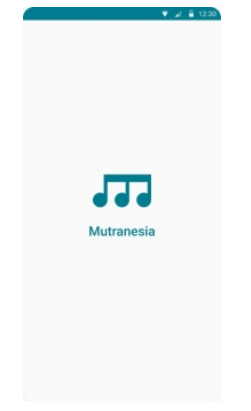

Figure 2. Splash Screen Display (Source : Aulia, Juni 2021)

Splash screen aims to display the initial appearance of an application, which appears a few seconds. Precisely for the loading process..

\section{Welcome page view}

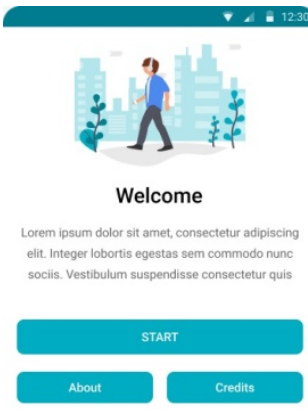

Figure 3. Welcome page view (Source : Aulia, Juni 2021)

This page displays an image and three buttons. Among them the start button, the about button and the credits button. There is also welcome information.

3. About page view

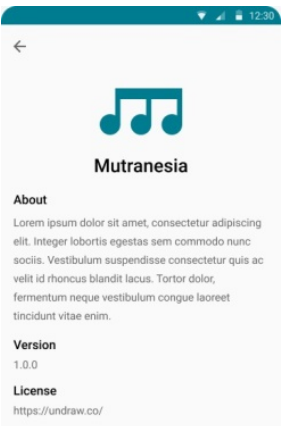

Figure 4. About page view (Source, Juni 2021)

About page to inform about the application starting from the application description, version and license..

4. Credits Menu Display

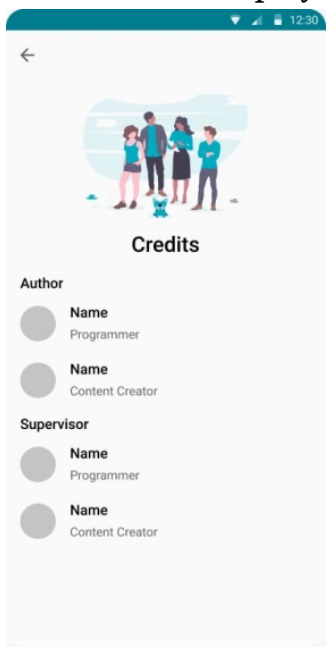

Figure 5. Credits Menu Display (Source: Aulia, Juni 2021)

Credits page to provide information on the people involved in making the app.

5. Map View 


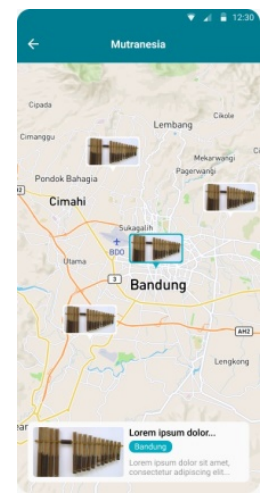

Figure 6. Map View Credits (Source : Aulia, Juni 2021)

After pressing the start button, a map page will appear in which images of traditional instruments that represent the area are listed. And a guide line will appear and when you press the instrument image, the instrument details will appear.

\section{Content Display}

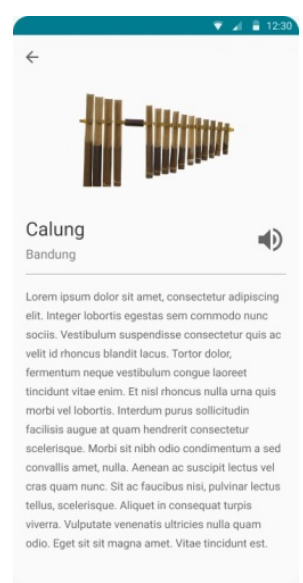

Figure 7. Credits page view (Source : Aulia, Juni 2021)

This content view will appear when you click on the instrument details. This content contains a description of the instrument in question. Starting from the history, how to play and there is a sound feature that can be sounded after pressing the sound symbol. .when the sound sounds, the color of the symbol will change to blue. When finished, the color of the sound icon will return to its original color.

\section{CONCLUSION}

Mutranesia application is an android-based music application. It has the concept of maps. Users can use this application by searching for an instrument whose image appears on the map listed..

Mutranesia application design is simply through the analysis stage, design stage and development stage. The application has been completed, the next step is to fill in the data for Indonesian traditional music, after filling it then proceed to the stage of implementing the application in the realm of formal and non-formal education. Especially for those who have traditional Indonesian music material.

\section{REFERENCES}

Asmara, D. A. (2020). Aplikasi Pengenalan Alat Musik Gamelan Jawa. Jurnal Transformasi, 16(1), 43-53.

Fathan, A., Irawan, R., \& Resmadi, I. (n.d.). PERANCANGAN MEDIA EDUKASI TENTANG PEMBELAJARAN DAN PEMELIHARAAN LINGKUNGAN HIDUP MELALUI NILAI-NILAI FILOSOFIS KARINDING.

https://bandung.kompas.com/read/2020/ 01/02/1709

Hidayati, K. H., \& Nafiiyah, N. N. (2017). Aplikasi Alat Musik Tradisional Gamelan Jawa Berbasis Android. Jurnal Teknika, 9(1), 10. https://doi.org/10.30736/teknika.v9i1.3 Mustika, G., Fujiawati, F. S., \& Permana, R. (2020). Aplikasi Mobile APPS Gamelan Untuk Pembelajaran Seni. Jurnal Pendidikan Dan Kajian Seni, 5(2), 162-170.

Oktarian, N. (2020). PERANCANGAN APLIKASI PEMBELAJARAN MUSIK GITAR BERBASIS ANDROID. In 
Jurnal Ilmiah Mahasiswa Teknik

Informatika (Vol. 2, Issue 3).

Saputra, D. I., Abdullah, A. G., \& Hakim,

D. L. (2013). Pengembangan Model

Evaluasi Pembelajaran Project Based

Learning Berbasis Logika Fuzzy.

Innovation of Vocational Technology

Education, 9(1), 13-34.

https://doi.org/10.17509/invotec.v9i1.50

89

Sasmito, G. W., Informatika, J. T.,

Bersama, H., Mataram, J., 09, N., \&

Lor, P. (2017). Penerapan Metode

Waterfall Pada Desain Sistem Informasi

Geografis Industri Kabupaten Tegal.

2(1).

Setiadi, A., Yuliatmojo, P., \& Nurhidayat,

D. (2018). Jurnal Pendidikan

Vokasional Teknik Elektronika Volume

I (Issue 1).

Guntoro.(2021). 6 Metode

Pengembangan Perangkat Lunak

Paling Populer.

https: / /badoystudio.com/metode-

pengembangan-perangkat-lunakl

(accessed 20 Juni 2021). 